\title{
The Right to Self-Preservation? Corporeal Considerations in the Leviathan
}

Candan Türkkan*

Özyeğin University

\begin{abstract}
Diverging from the readings that correlate it with right to self-defense, the paper offers a new look at the Hobbesian right to self-preservation and its conceptualization as a limit to the Leviathan's sovereignty. The paper argues that the subject's right to self-preservation should be read not solely in the context of external attacks, but also against subjects' own corporeal vulnerabilities (perishability, woundability and emotional vulnerability). The primary task of the Leviathan is thus to provide the necessary commodities, services, and infrastructures for the subjects' selfpreservation as much as to ensure their peace and security. While how the Leviathan is to provision these resources and how the subjects will preserve themselves remain open (a comprehensive welfare regime or a competitive, free market regime, etc.), failure to do so is contrary to the Leviathan's reason of existence and as such, voids the contract.
\end{abstract}

Keywords: Hobbes, classical sovereignty, vulnerability, limits of sovereignty, right to self-preservation

\section{Leviathan'da Bedensel Değerlendirmeler ve Kendini Koruma Hakkı}

\section{Özet}

Bu makale, kendini koruma hakkını, kendini savunma hakkından ayırarak Hobbes'un Leviathan eseri üzerinden devam eden klasik egemenliğin limitleri tartışmasına yeni bir bakış sunmaktır. Makale, öznelerin kendini koruma hakkının sadece dışarıdan gelen saldırılara karşı değil, öznelerin kendi bedensel kırılganlıklarına (çürüyebilirlik, yaralanabilirlik, duygusal kırılganlık) karşı da geçerli olarak okunması gerektiğini savunur. Nitekim Leviathan'ın en önemli görevi, barış ve güvenliği sağlamak kadar, öznelerin bu bağlamda kendilerini korumaları için gerekli altyap1, hizmet ve metaları temin etmektir. Leviathan'ın bu hizmet, altyapı ve metaları nasıl temin ettiği (kapsamlı bir sosyal devlet aracılığı ile mi yoksa rekabetçi serbest piyasa rejimi ile mi) net olmamakla beraber, bunların temin edilmemesi, Leviathan'ın varlık nedenine karşı olduğu için, toplumsal sözleşmeyi geçersiz kılacaktır.

Anahtar Kelimeler: Hobbes, kurllganlık, klasik egemenlik teorisi, klasik egemenliğin limitleri, kendini koruma hakkı

\footnotetext{
* Candan Türkkan, Assistant Professor. Özyeğin University Department of Gastronomy and Culinary Arts. Çekmeköy Kampüsü Nişantepe Mah. Orman Sk. 34794 Çekmeköy - İstanbul. Phone: +90(216) 56490 00. E-mail: candan.turkkan@ ozyegin.edu.tr. ORCID: 0000-0002-7814-3146 
$\mathrm{W}$ hether Hobbes could successfully limit the Leviathan's sovereignty by establishing the subject's right of self-preservation as an inalienable right is an ongoing political theoretical debate. For many interlocuters of Hobbes, including some of his contemporaries, this right, particularly in cases where the subject resists the sovereign to defend him/herself against the sovereign's sword, can become a route for legitimizing resistance and rebellion (Skinner, 2008). Scholars since then have underlined the puzzling role the right to selfpreservation has in the Hobbesian theory of sovereignty, presenting it as a contradiction that can negate the absolute sovereignty of the Leviathan (Hampton, 1995) or in the least, a juridicophilosophical Achilles Heel that needs to be resolved (Schrock, 1991; Steinberger, 2002; Warrender, 1957; Zarka, 2004; Dyzenhaus, 2001; Nagan \& Haddad, 2012; Sheridan, 2011). Aside from scholarly concerns over the consistency of Hobbes's thought and the conceptualization of sovereignty in the Leviathan, these discussions also proved to be fruitful venues through which limits of government could be explored. Particularly for the theorists of the liberal democratic thought writ large, right to self-preservation could be expanded to include a whole list of other rights or conflated with right to private property (Macpherson, 1990; Jaume, 2007; Lopata, 1973). Thus, historically conjoined to the discussions of slavery and colonialism, on the one hand, and resistance and rebellion, on the other, right to self-preservation had far-reaching theoretical and political-economic implications that continue to be relevant today.

In what follows, I aim to re-think right to self-preservation as neither a proxy for discussions on limits of government, nor a cover for a right to resistance nor an expansion of right to self-defense, but as a right onto its own that stems from some very human, perhaps even mundane, corporeal vulnerabilities that we all share. With corporeal vulnerability, I mean the imminence of death; the shifting of limits of one's mortality and endurance due to external or internal infringements; the breaking down of one's bodily order, harmony, constitution, and/or balance. Specifically, I will argue that three forms of corporeal vulnerability underlie in the theoretical lifeworld of the Leviathan: Perishability - unless properly and continuously maintained, the human body immediately surrenders to entropy, decaying and perishing in due time; woundability - unless protected, the human body can be easily injured and/or sickened, leading to weakness and death; and emotional vulnerability - awareness of one's own perishability and woundability. Constant fear of looming death - not only because of an enemy at the gates kind of situation, but also because of lack of food, or a mysterious miasma that suddenly descends onto the city or the village - pushes Hobbesian subjects and sovereign to overcompensate for their sense of insecurity and danger. They take measures for their own sake, which in the process may disregard or even threaten the lives of others. In the condition of conflict thus created, they are then further incentivized to act in ways that may put them in harm's way. It is these corporeal vulnerabilities and the conflicts that they give rise to make life in the state of nature "nasty, brutish and short" (Hobbes, 1996, p. 89), and help pre-contract individuals to be viscerally convinced of the need to institute a/the Leviathan.

In other words, subjects' self-preservation is the reason for the Leviathan's existence. Precontract individuals institute the Leviathan so that their lives are not "nasty, brutish and short" (Hobbes, 1996, p. 89). Yet, once the Leviathan is established, neither the corporeal vulnerabilities nor the conflicts they give rise to go away. Right to self-preservation too is maintained in the commonwealth as an inalienable natural right (or a natural liberty) (Skinner, 2008, p. 166). What differs with the presence of the Leviathan rather than its absence, then, is the prospect of a life for the subjects that is not "nasty, brutish and short" (Hobbes, 1996, p. 89) but is peaceful and comfortable, one in which languages, arts and sciences could flourish. Hence, the enforcement of 
the subjects' inalienable right to self-preservation entails the generation of conditions such that the subjects have the right to lead such a life.

And here is, where I differ from the literature. In the next section, Right to Self-Preservation in the Literature, I show thorough examples that in the literature, right to self-preservation tends to be conceptualized along the lines of right to self-defense, or right to resistance or even right to rebel. I will suggest that what these conceptualizations implicitly imagine is a scenario in which one exercises their right to self-preservation when confronted with an external attack that will lead to death or bodily harm that with a high likelihood of death. For scholars, where that external attack comes from - the sovereign or other people and in what state and under what circumstances it takes places - in the state of nature or in the commonwealth, as punishment or in a fight with a neighbor, etc. are critical. They explore possible different trajectories with an intention to weigh the legitimacy of the attack and the exercise of the right, on the one hand, and uncover the limits of Leviathan's sovereignty, on the other.

One need not an external attack to die, however. Our corporeal vulnerabilities do generate plenty of quite mundane occasions and opportunities for us to succumb to death on a daily basis. Thus, in the following section, Conservation or Preservation of Life: Vulnerability in the Leviathan, I situate perishability, woundability and emotional vulnerability in the Leviathan, and then go on to argue that if the reason for the institution of the Leviathan is the subjects' self-preservation, Leviathan has to make sure that conditions in which subjects may not be able to preserve themselves should not arise. To be clear, I am not suggesting that the Leviathan creates a conflictfree commonwealth in which no one ever attacks or harms one another. Rather, I am suggesting that we think about the subjects' right to self-preservation beyond cases when there is an active attempt and/or a threat to their 'end' life. For example, how would we think about subjects' right to self-preservation if (and these days, increasingly, when) the subjects are free, that is they are not bound by "external impediments that render movement impossible" (Skinner, 2008, p. 208), yet are unable to (due to poverty, for example) access food that they need to continue living? What if clean (non-toxic) drinking water is simply beyond their reach? What if working for a minimum wage (which may be below a subsistence wage) they eat less and less and suffer a death due to diet-related diseases? Or paradoxically perhaps, the food that they have to eat is so nutritionally poor yet calorie rich that it is not hunger but obesity-related diseases that takes them gradually? What of the right to self-preservation then?

As I will argue in the third and the final section, if the primary task of the Leviathan - the reason for its existence - is to enable a life for the subjects that is not "nasty, brutish and short" (Hobbes, 1996, p. 89), then the Leviathan must organize social, political, and economic domains around principles of sustenance. What this entails and/or how it will be done is up to Leviathan to decide: It can institute a comprehensive welfare regime for all subjects where the Leviathan itself provides the necessary services (healthcare, housing, food, retirement, etc.) or it appoints actors to do so (similar to what Macpherson describes as a possessive market society (Macpherson, 1990), for example) or some services are provided by the Leviathan and others by these actors, etc. Whichever the case - and I am not arguing for any of these per se, at least in this paper - Leviathan must provide the infrastructures, services, and goods that can generate the conditions (and perhaps also the resources) necessary for the subjects to preserve their lives. If it fails to do so, the contract becomes void and the subjects are thrown back to the state of nature. At the same time, the question of how the means of sustenance are going to be distributed - quickly puts us in the realm of politics (with both a small 'p' and, a la Carl Schmitt, capital 'P' (Schmitt, 1976)). Exploring what that 
entails, and equally importantly, what clues the Leviathan may offer to us for the classical theory of sovereignty, however, remains outside the scope of my discussion here.

On that regard, I should also note that I limit my discussion here to the Leviathan though there may be room to expand my arguments to the body of Hobbes's other works. It is not my intention to go into such a field-specific discussion on Thomas Hobbes, however. I will leave that, respectfully, to Hobbes scholars. What I am interested is thinking about the provisioning the dayto-day, mundane, socio-biological requirements for the preservation of life of the Leviathan's subjects, and the implications of such provisioning for the classical theory of sovereignty, of which Hobbes's Leviathan is the example par excellence.

\section{Right to self-preservation in the Literature}

Part of the reason why the right of self-preservation and the right of self-defense are so frequently conflated is the way in which we (Hobbes included) imagine men to be in the state of the nature. I will let Alan Ryan describe it:

We are to consider men in an ungoverned condition. They are rational, that is, able to calculate consequences, they are self-interested, at any rate in the sense that they ask what good to themselves will be produced by any given outcome, they are vulnerable to one another - you may be stronger than I, but when you are asleep, I can kill you as easily as you can kill me; they are essentially anxious. They are anxious because they have some grasp of cause and effect, understand the passage of time, and have a sense of their own mortality. (2006, p. 219)

Anxiety puts the men of state of nature on the edge, precisely because they are aware that they may not always access the resources they need to preserve themselves; and that is because, even if they work to obtain those resources, securing them to access them later might prove tricky. A resource problem, thus, quickly morphs into a security problem - both threatening their chances of survival, albeit for different reasons:

Hobbesian man is heedful of the future. This means that no present success in obtaining what he needs for survival can reassure him. I pick apples from the tree now, but know I shall be hungry in six hours, my obvious resource is to store the surplus apples somewhere safe. But the logic of anxiety is remorseless. Will the apples remain safe if I do not find some way of guarding them? I find myself in a terrible bind. In order to secure the future, I have to secure the resources for my future, but to secure them, I have to secure whatever I need to make them safe. And to secure it. . .. (ibid.)

For the men of the state of nature who are stuck in a 'security bind', then, self-preservation is strongly tied to self-defense. Apples need to be guarded against not their course of natural decay (which is why nobody is mentioning various apple preservation techniques - known since, we might expect, humanity discovered that apples were edible or soon after), but other men who can (and possibly will) make a claim over them. And, because capacities of men are roughly equal, "each appears to the other as a threat, and because each appears as a threat, each [becomes] a threat [to the other]" (ibid). In the imagined, unavoidable conflict over apples then, the men of the state of nature will have to defend themselves to preserve themselves. 
The conflation follows a different trajectory when the men are presumed to have exited the state of nature for the security of the commonwealth. The source of imagined threat this time is not the other men of equal right and equal capacity (and as Ryan adds, equal hope (2006, p. 220)) but the sovereign itself. Patricia Sheridan's robust analysis of the limits of sovereignty and possibilities of resistance in the Leviathan, for example, is tellingly titled "Resisting the Scaffold" (Sheridan, 2011). After underlining that for Hobbes, "each subject retains the natural right to protect herself from a physical threat, even if that threat comes from the sovereign" (ibid, p.149), Sheridan turns to the literature to point out that this natural right is conceptualized as "“a right to resistance"" (qtd. in Sheridan, 2011, p. 149) and that it may be the basis of popular dissent (ibid). Yet, such a reading, according to Sheridan, is misleading as it ignores that "civil liberties [which she argues self-preservation to be one] are justly exercised only in the event that they present no inconsistency with state authority" (ibid, p. 151; italics in original) and that "the sovereign is under no obligation to his or her subjects arising from their rights to self-defense" (ibid, p. 150). As such, Sheridan concludes, "what Hobbes seems to have in mind is a situation in which the individual under threat fully appreciates the state's reason for punishing him or her - fully accepting its laws and its sanctions but cannot under any conditions promise to do harm to herself by her own hand nor to peacefully face the imminent threat of pain or death" (ibid, p. 151).

Hannah Pitkin in her meticulous analysis of the concept of representation in works of Hobbes comes to the same conclusion after evaluating the tension between what she calls selfpreservation and corporeal punishment:

[Subjects] have agreed in advance that all the sovereign's actions should be their own, that is, should be treated exactly as if they themselves had done them. So if they were later to complain about something he did, or refuse to obey one of his commands, they would be complaining of themselves or refusing themselves. This is the point of Hobbes's famous dictum that the criminal is the author of his own punishment; his punishment then can be no injury to him (Pitkin, 1964b, p. 914).

Compared to Sheridan, Pitkin's Leviathan is much more potent and absolute. After pointing out that Hobbes uses rights to indicate "freedom from obligation" (Pitkin, 1964b, p. 911), Pitkin argues that the right to self-preservation or right to life "means only that I cannot be obliged to renounce my life. It does not mean that I am entitled to life so that others have a duty not to kill me, or even to keep me alive" (ibid). The sovereign, in turn, "has no obligation to his subjects" (ibid, p. 914); he only has "duties, which he must interpret in the lift of his own conscience, and for which he is responsible to God" (ibid). This implies that whatever the sovereign does, it is of no injustice to the subjects, and as such, his failure to abide by his "duties can never be made the basis for any claims on the sovereign by his subjects nor used to justify a revolt" (ibid).

As Susanne Sreedhar recognizes, however, the right of self-preservation is broader than "the right of self-defense" (Sreedhar, 2013, p. 11). It includes the right to self-defense, but it also refers "to the much broader right of nature" (ibid). Right of nature, for Sreedhar, is "the right of nature accords one the right to $\mathrm{X}$ if one believes that $\mathrm{X}$ is necessary for one's preservation (i.e., one believes one will die without $\mathrm{X}$ ), or if one believes that $\mathrm{X}$ contributes to one's preservation (i.e., one believes that doing X will further one's chances of preserving oneself)" (ibid, p. 12); whereas the right of self-defense refers to "tak[ing] measures to avoid imminent death" (ibid, p.11). For Sreedhar, establishment of the commonwealth requires restricting the right of nature "or else nothing would be given up in the social contract" (ibid). Indeed, her sharp analysis focuses on 
what such restrictions entail in specific situations. Where Hobbes "stands out" (ibid, p.9, footnote\#5), according to Sreedhar, is his non-discrimination with regards to "the source of a threat to one's preservation" (ibid); that is, he treats "threats of violence from the state, i.e. state-inflicted punishment (...) in the same manner as the danger in threats of violence from private individuals, and even the danger posed by lack of food or medicine" (ibid.) and entitles the subject the right to self-defense in each case so long as an imminent threat is present.

While Pitkin is signaling at the discussions on the limits of political obligation via the right to resist, for Quentin Skinner, what is at stake is not resistance, but liberty. Tracing the trajectory of the conceptualization of liberty throughout Hobbes's works, Skinner argues that liberty for Hobbes "consists of nothing more than the absence of external impediments" (p.157) and that "we retain an important element of our natural liberty even under legal systems of the utmost severity" (ibid). As such, though people obey laws out of fear of consequences, "when the preservation of our life or health is at stake, the arbitrary impediment constituted by our fear of consequences of disobeying the law will be insufficient to determine our will, as a result of which our natural liberty will remain unimpaired" (ibid, pp.157-8). As such, claims Skinner, according to Hobbes, "we remain at all times, and under all forms of government, entirely at liberty to disobey the laws whenever we want" (ibid, p.158). Such disobedience, however, does not necessarily lead to a right to resistance ( la Pitkin) or a right to self-defense (a la Sheridan). Rather, it leads to, what Skinner dubs as oxymoronic, 'inalienable natural right' - an expansive list of "liberties that can and must be retained" even in the commonwealth (ibid, pp.166-8). In other words, in Skinner's analysis, right to self-preservation figures not as a right per se, but as an expansive liberty, that puts the onus of consequences of exercising it on the subjects.

Yet, those consequences are critical. It is the fear of facing those consequences that makes people obey the laws in the commonwealth and pushes them into a security bind in the state of nature. In each case, however, what Hobbes's interlocutors imagine is the prospect of imminent death or of bodily harm with a strong possibility of death (see, for example; Sreedhar, 2013; Finkelstein, 2001; Baumgold, 1983). They do not consider other circumstances where death and/or corporeal harm may happen gradually due to, for example, lack of food and/or water ${ }^{1}$. Even Sreedhar's comprehensive analysis allocates a marginal role to hunger, starvation, famine, claiming that "although [the right to self-defense] is sometimes invoked in cases where the threat of death does not come from a physical attack (e.g., starvation), Hobbes most often conceives of it as a right to defend oneself from attacks by other people" (Sreedhar, 2013, p. 9). This is surprising since, as Sreedhar also recognizes, Hobbes considers lack of food as much of an imminent threat as state inflicted punishment (ibid, p.9, footnote\#5) and does not regard rebelling out of necessity (Jews at the Warsaw Ghetto in Sreedhar's example (ibid, pp. 143-8)) as violation of the social contract.

While Lisa Heldke's exploration of [political] philosophy's uneasy relationship with food (Heldke, 2006) might give us some idea as to why the expansive literature on the right to selfpreservation ignores the question of food (or the lack of it), reading the need for food or building a right to food into Hobbes's right to self-preservation is not too difficult to reckon with. Patricia Sheridan, for example, points out that for Hobbes, "there is a single natural right that is nontransferable, and that is the right to save oneself from 'death, wounds, and imprisonment.' (1.14,

\footnotetext{
${ }^{1}$ While I emphasize food here, as I will discuss later, the string of arguments I will be making extend to cover other necessities of sustenance, thus situating corporeality at the center of Hobbesian theory of sovereignty.
} 
69) Each subject retains the natural right to protect herself from a physical threat, even if that threat comes from the sovereign." (2011, p. 149). Sheridan uses this passage to build her reading of selfpreservation as right to resist. While it is certainly possible to read this passage as leading to the right to resist corporeal punishment inflicted by the sovereign, it is worth nothing that Hobbes does not specify what kind of death he is talking about. As such, the death in question that the subject retains to save him/herself from may as well be starvation. We know that hunger and scarcity were prominent existential struggles subjects waged daily at Hobbes's time (Livi-Bacci, 1991). Particularly in the urban milieu, conditions could easily worsen into famine and cause death en masse. Plus, wars, sieges, and military ventures - never in short-supply - put extra stress on the food systems, escalating the already tenuous availability into dire scarcity. Even in times of peace, sovereigns had to implement anti-scarcity measures to prevent such escalations; for public storehouses filled with grain, we are told, not only kept the subjects happy, but they also ensured relative independence from powerful and scheming neighbors (Machiavelli, 2016, p. 38). But it is not necessary to extrapolate from the zeitgeist; as I will discuss in the next section, once we acknowledge the centrality of corporeal vulnerability, right to food and even more broadly, right to sustenance become co-constituents of right to self-preservation.

\section{Conservation or Preservation of Life: Vulnerability in the Leviathan}

In the Leviathan, Hobbes refers to the preservation or conservation of (a person's) life multiple times throughout the text to indicate corporeal vulnerability as a consistent, underlying existential concern. Life, for Hobbes, is not a devoid-of-context 'given', but a force that needs to be preserved. His subjects, like him, get hungry, thirsty, tired, exhausted, aroused, hopeful, insecure, fearful, etc.; and as such, they can be gullible, suspicious, cowardly, or overzealous in their actions. Moreover, their state of being is never static; their bodies and minds are in constant flux - wanting to eat this moment, looking for a secluded spot to defecate the next. Life, as such, requires constant attention by those who embody it (and concomitantly - and perhaps perversely - by those who want to destroy it), for unless preserved, it will decay and succumb to death.

Hobbes's references to conservation or preservation of life correspond, roughly, to three forms of vulnerability I mentioned in the introduction: perishability, woundability and emotional vulnerability. Perishability refers to surrendering to entropy, decaying, rotting, withering in due time. For Hobbes, all "Earthly creatures" are perishable; and this includes the Leviathan, too "because he is mortal", says Hobbes, he is "subject to decay" (Hobbes, 1996, p. 221). To prevent perishing, in turn, life needs to recuperate: Subjects must drink clean (non-toxic) water, for example, they must eat nourishing foods (empty calories don't sustain in the long run); and they must rest and sleep. While how much one needs any of these might vary, the fact that one needs them does not. Indeed, it is to attain these resources that the pre-contract individuals "endeavor to destroy or subdue one another" (ibid, p.87) for they can be in the way of each other's "end (which is principally their own conservation, sometimes their delectation only)" (Hobbes, 1996, p. 87). Similarly, the pre-contract individuals can "by force, or wiles, (..) master" each other so that they "see no other power great enough to endanger [themselves]: and this is no more than [their] own conservation requireth, and is generally allowed" (ibid, pp.87-8). 
Woundability ${ }^{2}$ refers to the human body being easily injured and/or sickened, leading to weakness and death. Unlike perishability which indicates decay that comes due to inactivity against inherent tendencies of the body (not eating, not drinking water, not sleeping), woundability implies a breach of corporeal integrity - the breaking down of bodily unity, unhinging of barriers (physical, biochemical, psychological) between one's body and the outside; and as such, an inability to differentiate and regulate what is inside one's body (or, what makes up of one's body) and what is outside. Woundability is thus more than being gunned or knifed down in a dark alley. It encompasses susceptibility to hurt and succumbing to death, because of rape for example, or poison, abuse, or disease; it may indicate a loss of sense of self or grip on reality due to stress or trauma (think of extreme fear due to bodily harm or impending death, for example). Thus, if, for perishability, securing the means necessary to maintain one's body (food, water, rest) is the key, for woundability that key is protection - protection from assault, sickness, torment, exposure, or deprivation (which kills by playing on the body's perishability).

In general, subjects have two ways to beget protection: They can either obey a common power or fight for themselves. "The end of obedience," says Hobbes famously, "is protection" (1996, p. 153); fear of death and wounds as well as fear of oppression ${ }^{3}$ inspire civil obedience in subjects (Hobbes, 1996, pp. 70-2). Yet being an end, protection also constitutes a limit for the sovereign power. Subjects are obliged to obey "as long, and no longer than the power lasteth by which [the sovereign] is able to protect them" (ibid, p.153). When protection disappears, "the terrour of present death" (ibid, p. 208) compels the subjects to act to preserve their lives. For Hobbes, such a course of action is both a necessity and a right that cannot be transferred or made void (ibid, p.98; 202). Right of nature, as Hobbes called it, is indeed "the liberty each man hath, to use his own power, as he will himselfe, for the preservation of his own nature; that is to say, of his own life" (ibid, p.91). What thus fighting for one's self entails, however, is context dependent. For example,

[w]here a man is captive, or in the power of the enemy, (and he is then in the power of the enemy, when his person, or his means of living, is so,) if it be without his own fault, the Obligation of the Law ceaseth; because he must obey the enemy, or dye; and consequently such obedience is no Crime: for no man is obliged (when the protection of the Law faileth,) not to protect himself, by the best means he can. (Hobbes, 1996, p. 208)

Alternatively,

[w] hen a man is destitute of food, or other thing necessary for his life, and cannot preserve himselfe any other way, but by some fact against the Law; as if in a great famine he take the food by force, or stealth, which he cannot obtaine for mony nor charity; or in defence of his life, snatch away another man's Sword, he is totally Excused, for the reason next before alledged (ibid).

Even when threat of "corporeal hurt" (Hobbes, 1996, p. 206) comes from the sovereign, the subjects have a recourse to fight for themselves:

If the sovereign command a man (though justly condemned,) to kill, wound, or mayme himself; or not to resist those that assault him; or to abstain from the use of food, ayre,

\footnotetext{
${ }^{2}$ According to the OED, woundability (one "that may be wounded; susceptible of receiving wounds or physical injury") is one of the older meanings of vulnerability (2018, p. 2a).

${ }^{3}$ As are desire for ease, sensual delight, leisure, knowledge, and arts (Hobbes, 1996, pp. 70-2).
} 
medicine, or any other thing, without which he cannot live; yet hath man the Liberty to disobey. (ibid, p.151).

Woundability, as such, plays a double role: On the one hand, it cajoles the subjects to obey a common power; and on the other hand, under duress, it gives them a legitimate reason to disobey (Skinner, 2008; Ryan, 2006; Gert, 2006).

Woundability and perishability are not merely physio-chemical components of the subjects' corporeality, however. Subjects are also cognizant of their own vulnerabilities and their mortality. This awareness induces an existential fear, which may push them to act in previously unthinkable ways: "Not every fear justifies the action it produceth" (Hobbes, 1996, p. 206), argues Hobbes, "but the fear onley of coporeall hurt, which we call Bodily Fear, and from which a man cannot see how to be delivered, but by the action" (ibid; italics in original). Fear, thus, is a capable, efficient motivator. It compels subjects in the commonwealth to obey the Leviathan; or "where the Law cannot arrive time enough to [their] assistance" to their life "by wounding [those] that assaulteth [them]" (ibid). For individuals in the state of nature, in contrast, conditions are slightly bleaker. Because "nature hath made men so equall, in the faculties of body, and mind" (ibid, p.86), individuals (for they are not subjects to a sovereign yet) have "equality of hope in attaining of [their] ends" (ibid, p.87). The only way for individuals, who are cognizant of their vulnerabilities, to secure the means necessary for their subsistence is, then, to "endevour to destroy, or subdue one an other" (ibid.). This not only throws the individuals into a condition of "Warre (...) of every man, against man" (ibid, p.88), but also manifests in the form of a desire to be (more) powerful (than one's peers):

So that in the first place, I put for a general inclination of all mankind, a perpetual and restless desire of power after power, that ceased only in death. And the cause of this, is not always that a man hopes for a more intensive delight than he has already attained to; or that he cannot be content with a moderate power: but because he cannot assure the power and means to live well, which he had present, without the acquisition of more. (1996, p. 70)

This "restless desire" (Hobbes, 1996, p. 70) is not a vulnerability. It does become a vulnerability, however, when the individuals act on it, and by their actions, put themselves in harm's way. I am not talking about acting with the anticipation of preventing someone else's actions here. Rather, I am talking about a new course of actions being opened to the individual once s/he takes the preventive measures. In other words, "restless desire" becomes a vulnerability not when the individual "taking a journey, (..) armes himselfe, and seeks to go well accompanied" (ibid, p.89), but when the same individual decides, trusting he is armed and well-manned, that the journey is a good opportunity to assault and rob other travelers (who may or may not be similarly equipped). Such a course of action (or a change in the course of action), rooted in the desire to be more powerful, leads the individual to yet other desires, such as; "fame from new conquest", for example, "ease and sensual pleasure", "admiration or being flattered for excellence in some art", among others (ibid, p.70) - or simply, due to fear of looming death, secure the resources necessary for conservation or preservation of his/her life while s/he has the means to do so. Hobbes admits that although some of these ensuing desires may cause people to obey a common power or "do laudable actions" (ibid, pp.70-71), they also incline men to "contention, enmity and war" (ibid, p.70):

So that in the nature of man, we find three principal causes of quarrel. First, competition; secondly, diffidence; thirdly, glory. 
The first, makes men invade for Gain; the second, for safety; and the third, for reputation. The first use violence, to make themselves masters of other men's persons, wives, children and cattle; the second, to defend them; the third, for trifles as a word, a smile, a different opinion, and any other sign of undervalue, either direct in their persons, or by reflection in their kindred, their friends, their nation, their profession, or their name. (1996, p. 88)

Restless desire for more power ending only in death, which arises from cognizance of one's woundability and perishability thus further exacerbates the individual's vulnerability.

Hobbes's portrayal of the human condition in the Leviathan is such that its vulnerability breeds more vulnerability, or rather, its vulnerability creates situations in which it is more difficult to guard against vulnerability. At the same time, his account implies a form of reason in which the individuals make an effective cost-benefit analysis and decide to institute the commonwealth to control, maintain and/or to minimize their vulnerability. Their aim is to exit "the condition of war of everyone against everyone (...) [in which] every man has a right to everything; even to one another's body" (Hobbes, 1996, p. 91). ${ }^{4}$ This means, once the commonwealth is instituted and the sovereign is established, people will not have a right to each other's bodies; and in the condition of peace thus created, people will be able preserve or conserve their lives - put differently, they will be able to secure the resources necessary to maintain their bodies. For Hobbes, then, the primary aim in the institution of the political community is to live. Members transfer their right to "everything, even to one another's body" (ibid, p.91) to the Leviathan so that they can live.

The institution of the Leviathan as the common power and the subjection of individuals to its sovereignty do not mean that the struggles and conflicts due to vulnerabilities are over, however. They continue with two new caveats: First, the Leviathan (rather than the subjects themselves) becomes the ultimate adjudicator of conflicts. Indeed, Hobbes tasks the Leviathan with "hearing and deciding all controversies, which may arise concerning law, either civill, or naturall, or concerning fact" (Hobbes, 1996, p. 125). This is a critical task since without it subjects revert to the condition of war:

For without the decision of Controversies, there is no protection of one Subject, against the injuries of another; the Lawes concerning Meum and Tuum are in vaine; and to every man remaineth, from the naturall and necessary appetite of his own conservation, the right of protecting himselfe by his private strength, which is the condition of Warre; and contrary to the end for which every Commonwealth is instituted. (ibid.)

\footnotetext{
${ }^{4}$ Note that this conceptualization of vulnerability is significantly different than Judith Butler's conceptualization in Precarious Life: The Powers of Mourning and Violence. For Butler, vulnerability is integrally attached to grievablility, which comes from a collective recognition of each other's loss: "Loss has made a tenuous 'we' of us all. And if we have lost, then it follows that we have had, that we have desired and loved, that we have struggled to find the conditions for our desire" (2006, p. 20). This means that for each of us, vulnerability is both bodily and social; in fact, it is as bodily and so it is social:

Each of us is constituted politically in part by virtue of the social vulnerability of our bodies - as a site of desire and physical vulnerability, as a site of a publicity at once assertive and exposed. Loss and vulnerability seem to follow from our being socially constituted bodies, attached to other, at risk of losing those attachments, exposed to other, at risk of violence by virtue of that exposure. (ibid, p.20)

For Butler, loss and vulnerability are common denominators of humanity, whereby, through the process of mourning, they make it possible to (re)discover "ties we have with others" (2006, p. 22), and thus, "furnish a sense of political community of a complex order" (ibid).

For Hobbes, however, vulnerability is not a starting point for communal self-discovery, but a consistent existential state that requires active corporeal work to defend against.
} 
Second, the stakes of the conflicts over resources change. In the state of nature, conflicts between the pre-contract individuals lead to a condition of war and lives were staked. In the commonwealth, in contrast, such conflicts are (or, at least, supposed to be) not so fatal. The Leviathan, having been instituted to preserve the lives of the subjects (ibid, p.117), is (or, again, should be) a guarantor against such fatality. While death may occur due to conflicts, death as such is a crime; it is a result of injury, which is an injustice (ibid, p.104). To prevent them from happening - to the extent possible - Hobbes recommends that the Leviathan takes certain measures. For example,

Soveraign Ought to cause Justice to be taught, which (consisting in taking from no man what is his) is as much as to say, to cause men to be taught not to deprive their Neighbour, by violence, or fraud, of any thing which by the Soveraign Authority is theirs. Of things held in propriety, those that are dearest to a man are his own life, and limbs; and in the next degree, (in most men,) those that concern conjugall affection; and after them riches and means of living. Therefore, the People are to be taught, to abstain from violence to one anothers person, by private revenges; from violation of conjugall honour; and from forcibly rapine, and fraudulent surreption of one anothers goods. (ibid, pp.235-236).

To be clear, I am not saying that once the commonwealth is instituted nobody dies or that the Leviathan is responsible for preventing death, and when it fails to do so, it has to compensate the subjects for injuries (or injustices) done to them by their fellow subjects. What I am pointing out is that the Leviathan is tasked with protecting the subjects against the exploitation and/or exacerbation of their vulnerabilities such that they die. This implies that, for example, the subjects are not left without food, water and shelter so that they do not die of hunger, thirst, or exposure; they are protected against assault, rape, diseases, threats of physical or sexual violence; and perhaps most radically, even when, emboldened by their circumstances, they take actions that put them in harm's way, they are protected against potentially fatal consequences - of course, to the extent possible. It is crucial that the subjects' lives are preserved and given such conflicts (which are unavoidable due to equality of abilities and differences in manners), the possibility of a life that is not "nasty, brutish and short" (Hobbes, 1996, p. 89) exists in the commonwealth.

\section{Limits of Sovereignty}

If the Leviathan is constituted to live and life is therefore the foundation of sovereignty, then life does not remain outside the contract ${ }^{5}$; rather, it becomes an integral part of the contract. The Leviathan should do whatever in its power to ensure that the members of the political community can - and do - live: It may feed them, clothe them, provide shelter for them, protect them against breaches of their corporeal integrity, build sanitation infrastructure and direct other resources necessary for their health and hygiene, etc. In other words, whatever the Leviathan does, it should do with the aim to enable - by action and/or inaction - members of the political community to live. This is crucial for the Leviathan because it is both its duty and the reason for its existence. Plus, as Hobbes points out, there is no difference between the Leviathan and the political community itself (Hobbes, 1996, p. 224). As such, for its own preservation, as much as the subjects', the Leviathan must create and maintain the conditions necessary for the subjects' conservation.

\footnotetext{
${ }^{5}$ In contrast to Foucault, for example, who claims that life remains outside of the contract (see: (Society Must Be Defended: Lectures at College de France 1975-1976, 2003, p. 241))
} 
My emphasis on the conservation of life may sound like a call for a Leviathan that is even more absolute than the one Hannah Pitkin, for example, makes it out to be (Pitkin, 1964b; 1964a). After all, I am arguing that the Leviathan should undertake a wide variety of services to enable the subjects to live. It is however unclear - at least, looking solely at the Leviathan - by whom (public vs. private) and how (directly, as rights, for example, or indirectly, as commodities exchanged in the market, for example) these services are to be provided. In other words, there is no blanket recipe for the arrangement there should be between the state and the economy; or, whether the state or the private agents should undertake to provide the services, infrastructures, goods subjects need to survive; or, for that matter, what exactly such goods, services and infrastructures are (are communication services vital for subjects' subsistence, for example?). As such, the Leviathan could be a competition oriented, highly consumerist possessive market society (Macpherson, 1990, pp. 53-61), a rigidly organized, highly interventionist Polizeistaat (Foucault, 2008, pp. 5-9), or a neo(Ordo-)liberal Rechtsstaat that introduces "institutional corrections and innovations which will permit an economically regulated social order to be established on the market economy" (ibid, p.167). In either case, what is critical is that the Leviathan creates the conditions necessary for the subjects' self-preservation. Exactly how that is to be done remains open.

But, what if the sovereign fails? That is to say, what if the sovereign does not or cannot manage to generate the conditions necessary for the subjects to preserve themselves? It is not as if Hobbes leaves much recourse to the subjects. They cannot hold the sovereign accountable since s/he did not have a contractual obligation to begin with and was never subject to contractual terms and conditions (Sheridan, 2011; Pitkin, 1964b). Plus, his actions (or the lack thereof), according to Hobbes, do not constitute injustice:

whatsoever [the sovereign] doth, it can be no injury to any of his Subjects; nor ought he to be by any of them accused of Injustice. For he that doth any thing by authority from another, doth therein no injury to him by whose authority he acteth: But by this Institution of a Common-wealth, every particular man is Author of all the Soveraigne doth; and consequently he that complaineth of injury from his Soveraigne, complaineth of that whereof he himselfe is Author; and therefore ought not to accuse any man but himselfe; no nor himselfe of injury; because to do injury to ones selfe, is impossible. It is true that they that have Soveraigne power, may commit Iniquity; but not Injustice, or Injury in the proper signification. (1996, p. 124)

Finally, conceptually speaking, such a failure would not qualify as an external attack with a threat of bodily harm or death - which means subjects cannot claim rightful self-defense. In short, even if the sovereign fails to generate the conditions, provide the commodities, services, infrastructures, and others necessary for the subjects' self-preservation, subjects don't have any option but to go along with whatever present conditions are and to make the best of what they can of those conditions, of course while also obeying the laws the sovereign institutes for "the peace and defense of them all" both of which s/he is the judge of (Hobbes, 1996, p. 124).

This objection is critical. The response it merits, however, must address a distinction: How the sovereign fails. That is, if the sovereign fails because of lack of capacity (as in, if the sovereign simply cannot), or because the sovereign simply refuses to (as in, if the sovereign simply does not) generate the conditions, provide the services, infrastructures, etc. necessary for the subjects' selfpreservation. In the former case, capacity-building to better address the insufficiencies in the generation of conditions and providing of services, infrastructures, and etc. is clearly necessary; 
and while that may take time and there may be problems, setbacks, interruptions, and malfunctions in the meanwhile, it may be argued that the sovereign is still doing what s/he was authorized to do through the covenant.

The latter case, however, is tricky because of the way Hobbes constructs the relationship between the sovereign and the subjects in the Leviathan. To begin with, as absolute as the sovereign in the Leviathan may seem to be, s/he is not as absolute as to have the subjects' rights permanently transferred to him/her. Subjects maintain certain rights - what Skinner calls inalienable natural rights, or natural liberties (2008, p. 166). Not only that, but the subjects also become the authors of the sovereign's every action:

And in him consisteth the Essence of the Common-wealth; which (to define it,) is "One Person, of whose Acts a great Multitude, by mutuall Covenants one with another, have made themselves every one the Author, to the end he may use the strength and means of them all, as he shall think expedient, for their Peace and Common Defence. (Hobbes, 1996, p. 121)

This implies that a deliberate refusal on the part of the sovereign to take action to generate the conditions necessary for subjects' self-preservation is a refusal authorized by the subjects themselves. That, however, wouldn't make much sense. As Ellen Meiksins Wood concisely puts, "if the authors authorized a sovereign power to preserve their lives and their security, the sovereign may have unlimited rights to decide how to do this; but the one thing the authors cannot have authorized him to do is to fail at this task" (2012, p. 254). This is then, where the sovereign power ends, and the contract that brings that sovereign power along dissolves. The sovereign's refusal to provide means of sustenance to its subjects, to leave them to struggle on their own, with a high possibility of death and/or harm, suggests that the contract has been dissolved and that the subjects are now back in the pre-contract state of nature, where the "Warre Of Every One Against Every One" (Hobbes, 1996, p. 88) is perpetual.

\section{Conclusion}

This should come as a no surprise to us, since Hobbes himself puts it quite bluntly when he says, "The Obligation of Subjects to the Soveraign is understood to last as long, and no longer, than the power lasteth, by which he is able to protect them. For the right men have by Nature to protect themselves, when none else can protect them, can by no Covenant be relinquished" (1996, p. 153). What is surprising is perhaps the mundane, day-to-day acts the sovereign has to perform to provide such protection: provisioning of means of sustenance that the subjects so desperately need to preserve or conserve themselves. In other words, not solely the high politics (with a capital 'P') of war and peace and diplomacy, but the low politics of municipal works, and even more critically, of (re)distribution. Indeed, how would a Leviathan with such sensibilities deal with the water crisis in Flint, Michigan for example, or with a global pandemic that kills more of the poor than the rich and the powerful? How would it respond to tribalism- and racism-laden police brutality and to calls to abolish the police? Would such a Leviathan imprison journalists exposing the chronic corruption among the "Assembly of men" (Hobbes, 1996, p. 120) that constitute it and the villagers blocking the operations of an environmentally destructive mine or a dam that came to be as a result of such corruption? 
Thinking about subjects' right to self-preservation through our corporeal vulnerabilities has this uncanny consequence of having to confront some very difficult social and economic justice issues. If we were to take the other route, however, and followed the literature as I have suggested in the second section, we would have conceptualized the right to self-preservation as the subjects' right to self-defense and/or right to resistance, and we would have ended up neatly and squarely at the realm of law. Perhaps, we would have explored the differences between what was our right and what we were at liberty to do (or not to do), venturing off to discuss at what point, faced with conditions in which our rights were violated or our liberties extinguished, we would be entitled to rebel. It would not have been a futile discussion; but it would have ignored the day-today, mundane yet critical struggles of life that a corporeal vulnerability focused reading of the right to self-preservation, the kind that I aimed to do here, brings to the table.

To reiterate: When I say corporeal vulnerability, I am talking about perishability, woundability and emotional vulnerability. I am suggesting that these remain constant before and after the contract. Thus, what distinguishes the commonwealth from the state of nature is the protection the Leviathan provides - not just against external attacks, but also against the subjects' own corporeal vulnerabilities. Self-preservation as such is its reason of existence. Leviathan has to generate the conditions, provide the services, infrastructures, commodities, etc. necessary for subjects to exercise their right to self-preservation. Failure to do so voids the contract and throws subjects back to the state of nature, even though Hobbes leaves relatively unclear what sorts of arrangements the sovereign needs to make to generate such conditions and deliver the means of sustenance.

Going forward, perhaps it will be become necessary to clarify what those arrangements are (Macpherson's competitive, consumerist market society, Foucault's Rechsstaat and Ordo-/neoliberal market societies were some examples I mentioned). More importantly, I think, we will have to settle on what the Leviathan failure looks like. For, as I have argued, if it so happens that the Leviathan has already failed and we are back to the state of nature, it might be the perfect time to start drawing a new contract. 


\section{References}

Baumgold, D. (1983). Subjects and Soldiers: Hobbes on Military Service. History of Political Thought, 4(1), 43-64.

Butler, J. (2006). Precarious Life: The Powers of Mourning and Violence. New York: Verso.

Dyzenhaus, D. (2001, Sept.). Hobbes and the Legitimacy of Law. Law and Philosophy, 20(5), 461498.

Finkelstein, C. (2001). A Puzzle About Hobbes on Self-Defense. Pacific Philosophical Quarterly, $82,332-361$.

Foucault, M. (2003). Society Must Be Defended: Lectures at College de France 1975-1976. (A. I. Davidson, Ed., \& D. Macey, Trans.) New York: Picador.

Foucault, M. (2008). The Birth of Biopolitics: Lectures at the College de France 1978-1979. (A. I. Davidson, Ed., \& G. Burchell, Trans.) New York: Picador Palgrave MacMillan.

Gert, B. (2006). Hobbes's Psychology. In T. Sorell, The Cambridge Companion to Hobbes (pp. 157-174). Cambridge: Cambridge University Press.

Hampton, J. (1995). Hobbes and the Social Contract Tradition. New York: Cambridge University Press.

Heldke, L. (2006). The Unexamined Meal is Not Worth Eating. Food, Culture \& Society, 9(2), 201-219.

Hobbes, T. (1996). Leviathan (Revised Student Edition ed.). (R. Tuck, Ed.) New York: Cambridge University Press.

Jaume, L. (2007). Hobbes and the Philosophical Sources of Liberalism. In P. Springborg, The Cambridge Companion to Hobbes's Leviathan (pp. 199-216). Cambridge : Cambridge University Press.

Livi-Bacci, M. (1991). Population and Nutrition: An Essay on European Democgraphic History. Cambridge, UK: Cambridge University Press.

Lopata, B. B. (1973). Property Theory in Hobbes. Political Theory, 1(2), 203-218.

Machiavelli, N. (2016). The Prince (29 ed.). (Q. Skinner, R. Price, Eds., \& R. Price, Trans.) Cambridge, UK: Cambridge University Press.

Macpherson, C. (1990). The Political Theory of Possessive Individualism: Hobbes to Locke. New York: Oxfors University Press.

Meiksins Wood, E. (2012). Liberty and Property: A Social History of Western Political Thought from Renaissance to Enlightenment. New York: Verso.

Nagan, W. P., \& Haddad, A. M. (2012). Sovereignty in Theory and Practice. San Dierof International Law Journal, 13, 429-519. Retrieved from http://scholarship.law.ufl.edu/facultypub/293 
OED. (2018, March). vulnerable, adj. Retrieved from Oxford English Dictionary: http://www.oed.com.silk.library.umass.edu/view/Entry/224872?redirectedFrom=vulnerab le

Pitkin, H. (1964a). Hobbes's Concept of Representation-I. The American Political Science Review, 58(2), 328-340.

Pitkin, H. (1964b, Dec). Hobbes's Concept of Representation-II. The American Political Science Review, 58(4), 902-918.

Ryan, A. (2006). Hobbes's Political Philosophy. In T. Sorrell, The Cambridge Companion to Hobbes (pp. 208-245). Cambridge: Cambridge University Press.

Schmitt, C. (1976). The Concept of the Political. (G. Schwab, Trans.) New Brunswick, NJ: Rutgers University Press.

Schrock, T. S. (1991, Dec.). The Rights to Punish and Resist Punishment in Hobbes's Leviathan. Western Political Quarterly, 44(4), 853-890.

Sheridan, P. (2011). Resisting the Scaffold: Self-Preservation and Limits of Obligation in Hobbes' Leviathan. Hobbes Studies, 24, 137-157.

Skinner, Q. (2008). Hobbes and Republican Liberty: . Cambridge : Cambridge University Press.

Sreedhar, S. (2013). Hobbes on Resistance: Defying the Leviathan. New York: Cambridge University Press.

Steinberger, P. J. (2002, Oct.). Hobbesian Resistance. American Journal of Political Science, 46(4), 856-865.

Warrender, H. (1957). The Political Philosophy of Hobbes: His Theory of Obligation. Oxford: Clarendon Press.

Zarka, Y. C. (2004). The Political Subject . In T. Sorrel, \& L. Foisneau, Leviathan: After 350 Years (pp. 167-182). Oxford: Oxford University Press. 